Т. М. Думенко ${ }^{1}$, О. П. Яворовський ${ }^{2}$, М. М. Скалецький ${ }^{2,3}$, Р. П. Брухно 2 , Т. О. Зінченко ${ }^{2}$, М. М. Риган ${ }^{4}$

\title{
Пріоритетні проблеми системи фармаконагляду в формуванні безпеки пацієнтів і лікарняного середовища
}

\author{
${ }^{1}$ Державне підприємство «Державний експертний центр \\ Міністерства охорони здоров'я України», м. Київ \\ ${ }^{2}$ Національний медичний університет імені О. О. Богомольця, м. Київ \\ ${ }^{3}$ Державна установа «Інститут громадського здоров'я імені О. М. Марзєєва \\ Національної академії медичних наук України», м. Київ \\ ${ }^{4}$ Національний університет фізичного виховання і спорту України, м. Київ
}

Ключові слова: лікарські засоби, побічна дія, неефективність, медичні помилки, система фармаконагляду

Матеріали Всесвітньої організації охорони здоров'я (ВОО3) $[1,2]$, Організації економічної співпраці і розвитку (OECD) [3, 4] Всесвітньої асамблеї охорони здоров'я $[5,6]$ свідчать про зростаючий інтерес світової спільноти до проблеми безпеки пацієнтів.

Безпечне застосування лікарських засобів є одним з пріоритетних завдань сучасної охорони здоров'я [7].

За даними ВОо3, у країнах з високим рівнем прибутку за надання стаціонарної медичної допомоги шкода заподіюється кожному десятому пацієнту. У світовому вимірі за умов надання первинної й амбулаторної медичної допомоги шкода заподіюється чотирьом з 10 пацієнтів. Найсерйозніші наслідки мають помилки за умов діагностики захворювань, а також призначення та використання лікарських засобів [8].

Дані світової статистики свідчать, що загибель 4,8 млн осіб на рік пов'язана 3 дефектами надання медичної допомоги. За різними оцінками в США від таких дефектів щорічно вмирають понад 100 тис. осіб, у Великій Британії - 70 тис., у Німеччині 100 тис., в Італії - 90 тис. [9].

За даними FDA, у CША щорічно помирає близько 7 тис. пацієнтів унаслідок помилок, що пов'язані з використанням лікарських засобів [10].

(с) Колектив авторів, 2020
Щорічні світові витрати, пов'язані з помилками медикаментозної терапії, складають 48 млрд дол. США. I це ще без врахування втраченого прибутку, зниження працездатності та медичних витрат [8].

Однією 3 найважливіших складових раціонального та безпечного застосування лікарських засобів є робота системи фармаконагляду.

Мета дослідження - на основі даних аналізу літератури й електронних інформаційних баз визначити пріоритетні проблеми фармаконагляду для створення безпеки пацієнтів і безпечного лікарняного середовища.

Матеріали та методи. Досліджували дані наукової літератури та офіційної статистики ДП «Державний експертний центр МОЗУ» (ДЕЦ). На основі даних літератури оцінено роль побічних реакцій лікарських засобів, медичних помилок і випадків неефективності їхнього використання у формуванні небезпек лікарняного середовища, оцінено причинні фактори їхнього виникнення, значимість системи фармаконагляду для їхнього попередження.

Дослідження виконано з використанням бібліосемантичного аналізу (інформаційно-аналітичного узагальнення даних із наукових літературних джерел).

Дослідження проводено за програмою НДР «Наукове обгрунтування оптимальної системи управління ризиками для забезпечення безпечного 
лікарняного середовища», яка виконується на кафедрі гігієни та екології № 2 Національного медичного університету імені О. О. Богомольця на замовлення Міністерства охорони здоров'я України (державний реєстраційний номер: 0120U101432).

Даний аналіз літератури є однією 3 перших ланок у низці досліджень, спрямованих на вивчення безпечності закладів охорони здоров'я для медичного персоналу, пацієнтів, відвідувачів, можливого впливу закладу на навколишнє середовище. Отримані результати будуть використані для обгрунтування системи управління ризиками в закладах охорони здоров'я, розробки профілактичних заходів, формування концепції та практичної реалізації безпечного лікарняного середовища.

Результати та їх обговорення. Після талідомідової трагедії в 60-ті роки минулого століття здійснення нагляду за безпекою препаратів під час їхнього медичного застосування стало для переважної більшості країн світу одним 3 основних напрямів національної політики в галузі медицини.

Національні системи фармаконагляду, які здатні відіграти важливу роль в убезпеченні пацієнта шляхом корекції ризиків виникнення побічних дій $\mathrm{i}$ помилок за використання лікарських засобів і попередження неефективності медикаментозної терапії, продовжують активно розвиватися й дотепер.

За визначенням ВООЗ, фармаконагляд - це практична діяльність, пов'язана з виявленням, оцінкою, розумінням і профілактикою несприятливих негативних наслідків або будьяких інших проблем, пов'язаних 3 лікарськими засобами. Основна увага в системі фармаконагляду спрямована на побічні реакції лікарських засобів і випадки відсутності ефективності за їхнього медичного застосування [11].

Система фармаконагляду та безпеки лікарських засобів представляє собою координовані та взаємопов'язані дії, спрямовані на підвищення користі та зменшення шкоди від застосування лікарських засобів [12].

На момент реєстрації лікарських засобів дані щодо їхньої безпеки є неповними, оскільки отримуються переважно з попередніх експериментальних і передреєстраційних клінічних досліджень. Останні проводяться за обмеженої експозиції пацієнтів i $€$ короткотривалими, коли досліджуються певні дози лікарського засобу, що звужує перспективу виявлення та оцінки побічних реакцій досліджуваного лікарського засобу. Тому існує необхідність продовжувати спостереження за безпекою лікарського засобу після його реєстрації за подальшого широкого медичного застосування [12].

Післяреєстраційний нагляд $€$ критично важливим щодо виявлених під час клінічних досліджень побічних реакцій, у тому числі й таких, що раніше не були виявлені, для оцінки ефективності лікарських засобів у разі їхнього застосування в реальних клінічних умовах, а також із метою зменшення несприятливих наслідків, пов'язаних 3 виникненням побічних реакцій [12].

Основними завданнями фармаконагляду є збір, аналіз та узагальнення інформації про безпеку, побічні реакції та відсутність ефективності лікарських засобів, а також підготовка пропозицій для відповідальних органів про повну або часткову заборону лікарських засобів, внесення доповнень чи змін до інструкцій щодо їхнього медичного застосування.

Основними цілями фармаконагляду $\epsilon$ [13-14 ]:

- підвищення безпеки та ефективності застосування лікарських засобів;

- визначення співвідношення між користю та шкодою лікарських засобів й оцінка його прийнятності;

- сприяння взаєморозумінню всіх зацікавлених сторін (пацієнтів, лікарів, фахівців із фармаконагляду, держави) щодо оцінки безпеки лікарських засобів;

- підтримка програм охорони здоров'я шляхом надання необхідної інформації для оцінки співвідношення користь/ризик;

- підвищення ефективності комунікації між медичними працівниками, державою, громадськістю, засобами масової інформації.

У всьому світі все гострішою постає 
проблема раціонального застосування лікарських засобів. Побічні реакції, відсутність ефективності та медичні помилки за умов застосування лікарських засобів $є$ найважливішими точками впливу системи фармаконагляду задля досягнення безпеки пацієнтів і безпечного лікарняного середовища.

За даними дослідження, проведеного у США, небажані наслідки застосування лікарських засобів сприяли подовженню термінів госпіталізації пацієнтів у $1,5-2,0$ разу [15].

Побічні реакції - це одна з основних небезпек за використання лікарських засобів, їня чисельність невпинно зростає. Так, у 1991 році ВООЗ отримала повідомлення про більше ніж 1 млн випадків побічної дії лікарських засобів. У 2001 році таких повідомлень було понад 3 млн, а в 2009 році - понад 4 млн повідомлень [16].

За результатами фармаконагляду в Україні протягом 1996-2010 років у базі даних ДЕЦ налічувалося 43600 спонтанних повідомлень про побічні реакції [17].

Найчастіше виникали побічні реакції типу А (які залежать від дози) i реакції типу В (які не залежать від дози) - 75 і $20 \%$ відповідно [17].

Серед повідомлень про побічні реакції типу В 5,5 \% - про серйозні побічні реакції, які мали тяжкий перебіг (анафілактичні реакції, синдром СтівенсаДжонсона, токсичний епідермальний некроліз, ангіоневротичний набряк, анафілактичний шок) [17].

Серйозні анафілактичні реакції становили 3,0 \% від загальної кількості побічних реакцій. Вони проявлялися анафілактичним шоком, падінням артеріального тиску, бронхоспазмом або ангіоневротичним набряком, кропив'янкою чи декількома зазначеними симптомами одночасно. Найчастіше такі реакції виникали за використання антибактеріальних засобів для системного застосування, кровозамінників, перфузійних розчинів, анестетиків й аналгетиків [17].

Серед антибактеріальних лікарських засобів для системного застосування шкірні реакції найчастіше викликали цефтриаксон, амоксицилін, амоксици- лін з ферментами та цефазолін. Диклофенак, німесулід, ібупрофен і кеторолак - ті нестероїдні протизапальні препарати (НПЗП), які найчастіше викликали зміни з боку шкіри [17].

Анафілактичні реакції типу набряку гортані спостерігалися за медичного застосування місцевих анестетиків, антибактеріальних засобів для системного застосування, інгібіторів АПФ, кровозамінників і перфузійних розчинів, периферичних вазодилататорів, НПЗП, рідше - антинеопластичних, гормональних, протиастматичних, психолептичних, спазмолітичних лікарських засобів [17].

У 2011-2019 роках спостерігалася чітка тенденція до збільшення кількості повідомлень про побічну дію лікарських засобів в Україні.

У 2011 році до ДЕЦ надійшло 11347 повідомлень (у 8918 випадках було доведено причинно-наслідкові зв'язки) [18]. Протягом 2012 року до ДЕЦ надійшло 11674 повідомлень про випадки побічних реакцій і відсутність ефективності лікарських засобів. У 13,0 \% із них описувалися серйозні побічні реакції, а в $0,7 \%$ повідомлень йшлося про непередбачені побічні реакції. У понад 200 випадках було виявлено медичні помилки. У 19 повідомленнях лікарі інформували про відсутність ефективності лікарських засобів. Також зафіксовано 10 летальних випадків, щодо яких було встановлено причинно-наслідковий зв'язок з прийомом ліків [19].

У 2013 році в ДЕЦ було зареєстровано 19655 повідомлень, у 2014 році 16970 , у 2015 році - 19878 [13].

Станом на 2016 рік у базі даних уже нараховувалося понад 129 тис. повідомлень про побічні реакції [13].

У 2017 році до ДЕЦ надійшло 26056 валідних повідомлень про виникнення побічних реакцій за використання лікарських засобів, у 2018 році 23561 , у 2019 році - 26370 [20-22].

Найбільша частка повідомлень про побічні реакції в 2 півріччі 2019 року стосувалась застосування лікарських засобів, що діють на мікобактерії, та антибактеріальних засобів для системного застосування. На долю цих фармакотерапевтичних груп припадала майже 
половина всіх повідомлень. Така сама тенденція спостерігалася й у попередні роки.

Серед загальної кількості отриманих повідомлень про випадки побічних реакцій в другому півріччі 2019 року 91,9\% становили несерйозні побічні реакції та 8,1 \% - серйозні. Частота серйозних побічних реакцій за причинами серйозності становила: 0,44 \% смерті, 22,30 \% - загрози життю, $20,24 \%$ - госпіталізації амбулаторних пацієнтів, 34,30 \% - подовження термінів госпіталізації, 2,70 \% - тривала непрацездатність, 1,57 \% - інвалідність і 17,70 \% інші медично важливі стани здоров'я [22].

В. I. Леванда та співавт. вказують на те, що, за даними світової статистики в осіб, які лікуються амбулаторно, число ускладнень від фармакотерапії становить 2-3\%, а в тяжкохворих, які лікуються в стаціонарі, - до 35 \%. Летальність від побічних реакцій посідає 5 місце в світі після серцево-судинних захворювань, захворювань легень, онкологічних захворювань, травм. У США річні витрати на лікування даних ускладнень складають близько 76,6 млрд дол. США, у Великій Британії - 4 млрд дол. США, а загалом у різних країнах світу становлять $5,5-17,0 \%$ загального бюджету лікарень [16].

$\mathrm{Ha}$ частку несприятливих побічних реакцій сьогодні припадає до 5 \% від усіх випадків госпіталізації. Суттєво збільшується вартість лікування, знижується ступінь довіри до лікаря та методу лікування, погіршується якість життя, смертність становить 0,10-0,01 \% [15].

Основними факторами, що зумовлюють виникнення побічної дії за використання лікарських засобів, прийнято вважати наступні [16]: особливості організму хворого (вік, стать, шкідливі звички тощо); зовнішні, щодо хворого, фактори (екологічне оточення, умови праці та ін.); особливості клініко-фармакологічної характеристики лікарського засобу; адекватність вибору препарату; метод застосування препарату; взаємодія лікарських засобів у разі поліпрагмазії; постійне зростання чисельності генеричних лікарських засобів; порушення умов зберігання та застосування лікарських засобів після закінчення терміну придатності; самолікування; недоброякісна реклама лікарських засобів; широке розповсюдження біологічно активних добавок (БАД) та їхнє безконтрольне призначення.

Поряд із побічними реакціями, серйозну небезпеку для пацієнта становить неочікувана відсутність терапевтичної ефективності лікарського засобу. До основних причин відсутності ефективності R. Mеyboom та співавт. відносять наступні [23-24]:

- застосування підроблених лікарських засобів;

- використання генериків із низькою біодоступністю;

- порушення зберігання чи транспортування лікарських засобів;

- порушення обміну лікарських засобів у організмі;

- невідповідність дози препарату чи тривалості лікування;

- застосування лікарських засобів не за показаннями;

- резистентність збудників інфекції чи злоякісних клітин до діючої речовини препарату;

- фармакогенетична резистентність;

- толерантність і тахіфілаксія.

Адекватний моніторинг ефективності лікарських засобів системою фармаконагляду в ранньому післяреєстраційному періоді дозволяє впливати на дані причини та запобігати виникненню проблеми неефективності ліків.

Важливою складовою небезпеки лікарняного середовища $€$ помилки, які допускаються за умов застосування лікарських засобів. Одним із найважливіших завдань фармаконагляду $є$ їхнє виявлення та попередження [25].

ВООЗ виділяє 5 категорій медичних помилок, пов'язаних зі застосуванням ліків [26]:

- нераціональний вибір лікарських засобів;

- помилки відпуску/видачі лікарських засобів;

- помилки виробництва, зберігання та підготовки до використання лікарських засобів;

- помилки введення лікарських засобів;

- помилки моніторингу лікарської терапії. 
За даними ВООЗ, помилки застосування лікарських засобів, крім іншого, можуть бути наслідком втоми медичних працівників, високої нервово-емоційної напруженості праці, перевантаженості лікарень, нестачі персоналу, низького рівня підготовки й надання пацієнтам неправильної інформації. Ці причини окремо або в поєднанні одна з іншою можуть мати негативний вплив на процеси призначення, видачі/відпуску, прийому лікарських препаратів i моніторингу курсу лікування, що в кінцевому результаті може призвести до серйозного збитку для здоров'я пацієнта, інвалідності та навіть смерті [27].

Зростанню частоти помилок при застосуванні лікарських засобів також сприяє вплив на медичних працівників несприятливих умов праці, постійне нервово-емоційне перенапруження медичного персоналу, пов'язане з високою небезпекою праці (наприклад, в умовах боротьби 3 пандемією COVID2019), відповідальністю за здоров'я та життя пацієнта, позмінною роботою, вимушеним сумісництвом.

Підвищує ризик виникнення помилок і низька культура безпеки застосування медичних препаратів серед пацієнтів та лікарів.

У США понад $25 \%$ усіх медичних помилок обумовлені плутаниною в схожих найменуваннях ліків, а $33 \%$ помилок пов'язані зі застосуванням неправильного препарату в зв'язку зі схожістю оформлення упаковок [26].

За даними ЕMA, в Європі за надання амбулаторної допомоги частота помилок становить 7,50 \% на етапі виписування рецептів і 0,08 \% на етапі відпуску препарату; у стаціонарі частота помилок сягає $9,1 \%$ на етапі вибору й $2,1 \%$ на етапах відпуску та введення лікарських засобів [26].

Результати досліджень, проведених в Англії, свідчать, що помилки в призначенні лікарських препаратів або в плані ведення пацієнтів зустрічаються в кожного 8-го хворого, кожен 20-й лікарський препарат призначається невірно, у кожному 550-му рецепті містяться рекомендації, здатні призвести до тяжких наслідків для хворого [26].
Найпоширенішими помилками були: неповна інформація в рецепті, неправильний підбір дози, режиму дозування, відсутність належного спостереження та контролю за необхідними показниками після початку лікування [26].

За амбулаторного лікування в 26-87 \% випадків існують відмінності між тими лікарськими препаратами, які приймає пацієнт, i тими, що записані в його медичній документації, це збільшує ризик помилок, пов'язаних з несприятливими лікарськими взаємодіями [26].

Переведення хворого з одного відділення в інше також пов'язане з ризиком скоєння медичних помилок. Орієнтовно у кожного 6-го пацієнта змінюється раніше призначена схема лікування в разі переведення в інше відділення [26].

За даними досліджень, проведених у РФ А. В. Кузьміною та співавтор., частота медичних помилок за використання антибактеріальних препаратів групи цефалоспоринів виявлена в $25,2 \%$ спонтанних повідомлень, які надходили в російську базу даних небажаних реакцій у 2012-2014 роках. У 13,1\% із цих випадків у лікуванні пацієнта було допущено одночасно 2 і більше помилок. Найпоширенішим видом медичних помилок $(35,9$ \%) було призначення антибіотика за відсутності показань/за незареєстрованим показанням [28]. Частота медичних помилок за умов використання антибактеріальних препаратів групи карбапенему становила 24,8 \% призначень. Найпоширенішими видами медичних помилок $(44,0 \%)$ у разі використання карбапенемів є різні порушення дозового режиму. У більшості випадків $(20,0 \%$ усіх виявлених помилок) антибіотик вводили з меншою частотою, ніж того вимагає інструкція для медичного застосування [28].

Для зменшення частоти медичних помилок, розвитку побічних реакцій та запобігання випадкам неефективності лікарських засобів рекомендовано використовувати наступні заходи [16]:

1) розробку нових клінічних настанов $i$ стандартів лікування, які базуються на доказовій медицині та включають інформацію стосовно профілактики небажаних результатів лікування; 
2) удосконалення системи підготовки фахівців, що працюють на всіх рівнях надання медичної допомоги;

3) своєчасне та повне надання медичним і фармацевтичним працівникам необхідних відомостей про можливі несприятливі ефекти лікарських засобів;

4) поліпшення комунікації між медичними працівниками різних спеціальностей і на різних етапах надання медичної допомоги, їхньої взаємодії з представниками фармацевтичної галузі, пацієнтами;

5) розширення в лікарнях і поліклініках служби клінічних фармакологів;

6) розробку та впровадження в медичну практику нових лікарських засобів із вищим профілем безпеки та нижчою ймовірністю розвитку побічних дій;

7) створення безпечних i комфортних умов праці для медичного персоналу, що зменшить ризик скоєння помилок за використання лікарських засобів;

8) збільшення доступності якісних i безпечних лікарських засобів для всіх верст населення;

9) проведення освітньої роботи серед населення 3 метою прищеплення культури безпечного застосування лікарських засобів;

10) жорстке регулювання правил оприлюднення реклами лікарських засобів.

Значну частину $з$ цих заходів здійснює система фармаконагляду. Вона дає можливість оптимізувати застосування обмежених ресурсів на охорону здоров'я та запобігти потенційним лікопов'язаним проблемам i трагедіям, що робить їі важливою складовою убезпечення пацієнта та створення безпечного лікарняного середовища $[12,18]$.

Як можна бачити 3 даного огляду літератури, проблема раціонального та безпечного застосування лікарських засобів є вкрай актуальною та широко досліджується в усьому світі вже протягом багатьох років.

Не стояла осторонь цього процесу й Україна. На початку минулого десятиліття фахівцями Львівського національного медичного університету імені
Данила Галицького у співпраці з експертами ДЕЦ (А. Б. Зіменковський, О. В. Матвєєва, В. П. Яйченя, О. П. Вікторов, І. О. Логвіна, І. В. Струкова, В. А. Васильєва, О. Л. Хоромська, О. І. Євко, Н. М. Євтушенко, І. В. Підлісна, О. Б. Борецька, О. Ю. Городнича, Т. В. Ривак та інші) було виконано низку досліджень, спрямованих на вивчення проблеми ліко-пов'язаних помилок у контексті безпечного застосування лікарських засобів $[12,14,17$, 23, 29-32].

Проте попри велику кількість попередніх досліджень проблема безпеки лікарських засобів у контексті формування безпечного лікарняного середовища залишається не до кінця вивченою та потребує подальшого опрацювання.

\section{Висновки}

1. Проблема безпеки лікарняного середовища $є$ актуальною для всіх країн і всіх систем охорони здоров'я, а безпечне застосування лікарських засобів $€$ однією 3 найважливіших іï складових.

2. Побічні реакції ліків, медичні помилки та випадки неефективності, які виникають під час використання лікарських засобів, є важливою складовою небезпеки лікарняного середовища. Вони є найважливішими ланками впливу системи фармаконагляду щодо формування безпечного лікарняного середовища.

3. Функціонування системи фармаконагляду відіграє важливу роль в убезпеченні пацієнта шляхом зменшення ризиків виникнення побічних дій і помилок за використання лікарських засобів, попередження неефективності медикаментозної терапії та здатне оптимізувати витрати на систему охорони здоров'я.

4. Розробка нових і вдосконалення існуючих підходів до профілактики несприятливих наслідків медикаментозної терапії є вкрай актуальними та необхідними в умовах сучасної медицини. Ці заходи в світовому масштабі дозволять врятувати мільйони життів та сприятимуть економії матеріальних ресурсів. 
1. Patient Safety. Making health care safer. Geneva: World Health Organization. 2017. 20 p. URL: https://apps.who.int/iris/bitstream/handle/ 10665/255507/WHO-HIS-SDS-2017.11-eng.pdf?sequence=1\&isAllowed $=\mathrm{y}$.

2. Patient Safety Fact File. Geneva: World Health Organization; 2019. 13 p. URL: https://www.who.int/ features/factfiles/patient_safety/patient-safety-fact-file.pdf?ua=1.

3. Slawomirski L., Auraaen A., Klazinga N. The economics of patient safety : Strengthening a valuebased approach to reducing patient harm at national level. OECD Health Working Papers. 2017. № 96. Paris: OECD Publishing. http://dx.doi.org/10.1787/5a9858cd-en.

4. Slawomirski L., Auraaen A., Klazinga N. The Economics of Patient Safety in Primary and Ambulatory Care. Flying blind. 2018. Paris: OECD Publishing. 49 p. URL: https://www.oecd.org/health/healthsystems/The-Economics-of-Patient-Safety-in-Primary-and-Ambulatory-Care-April2018.pdf.

5. Безопасность пациентов. Водоснабжение, санитария и гигиена в учреждениях здравоохранения. Доклад Генерального директора Всемирной организации здравоохранения. Семьдесят вторая Сессия Всемирной Ассамблеи Здравоохранения A72/27 Пункт 12.5 предварительной повестки дня 25 марта 2019 г. URL: https://apps.who.int/iris/bitstream/handle/10665/328715/A72_27-ru.pdf?sequence=1\&isAllowed=y.

6. Глобальные действия по обеспечению безопасности пациентов. Доклад Генерального директора. Женева : Всемирная организация здравоохранения; 2019. URL: https://apps.who. int/gb/ebwha/pdf_files/WHA72/A72_26-en.pdf.

7. Безопасность применения лекарственных средств у детей - данные международного мониторинга за 50 лет. Б. К. Романов, Ю. В. Олефир, Р. Н. Аляутдин и др. Безопасность и риск фармакотерапии. 2019. № 7 (2). С. 57-64. https://doi.org/10.30895/2312-7821-2019-7-2-57-64.

8. Всемирная организация здравоохранения: 10 фактов о безопасности пациентов. URL: https:// www.who.int/features/factfiles/patient_safety/ru/ (дата звернення: 06.05.2020).

9. Проблема безопасности пациентов в медицинских организациях - взгляд практикующих врачей. В. В. Шкарин, В. В. Ивашева, Н. В. Семенова и др. Вестник ВолГМУ. 2018. № 4 (68). C. 107-109. URL: https://cyberleninka.ru/article/n/problema-bezopasnosti-patsientov-v-meditsinskih-organizatsiyah-vzglyad-praktikuyuschih-vrachey (дата звернення: 05.05.2020).

10. Ошибки применения лекарственных препаратов: современное состояние проблемы. А. В. Кузьмина, И. Л. Асецкая, С. К. Зырянов, В. А. Поливанов. Лечебное дело. 2015. № 3. С. 17-27 URL: https://cyberleninka.ru/article/n/oshibki-primeneniya-lekarstvennyh-preparatov-sovremennoesostoyanie-problemy.

11. Державний експертний центр МОЗ України: Фармаконагляд. URL: https://dec.gov.ua/materials/ pharmacovigilance/ (дата звернення: 20.05.2020).

12. Lebega O., Nwokike J., Walkowiak H. Safety of Medicinal Products in Ukraine: Assessment of the Pharmacovigilance System and its Performance. Submitted to the U.S. Agency for International Development by the Strengthening Pharmaceutical Systems (SPS) Program. Arlington, VA: Management Sciences for Health, 2012.

13. Барміна Г. Контроль за безпечним застосуванням ліків у центрі уваги українських та зарубіжних експертів. Apteka.ua. 2016. № 41 (1062). URL: https://www.apteka.ua/article/388665 (дата звернення: 20.05.2020).

14. Безпека та нормативно-правовий супровід лікарських засобів: від розробки до медичного застосування (пам'яті професора, д. м. н. Вікторова Олексія Павловича). О. В. Матвєєва, I. О. Логвіна, I. В. Струкова та ін. Новини медицини та фармації. 2016. № 14. C. 5-6. URL: http:// www.mif-ua.com/archive/article/43920 (дата звернення: 21.05.2020).

15. Косарев В. В., Бабанов С. А. Побочные эффекты лекарственной терапии: оценка и прогнозирование. Медицина невідкладних станів. 2010. № 6 (31). URL: http://www.mif-ua.com/archive/ article/15118.

16. Побічна дія лікарських засобів як фактор ускладненого перебігу периопераційного періоду. Л. І. Леванда, М. С. Опанасенко, О.В.Терешкович та ін. Украинский пульмонологический журнал. 2017. № 2. Додаток. С. 39-44. URL: http://www.ifp.kiev.ua/doc/journals/upj/17_dop/39. pdf (дата звернення: 06.05.2020).

17. Аналіз спонтанних повідомлень про побічні реакції на лікарські засоби. О. В. Матвєєва, О. П. Вікторов, В. Є. Бліхар та ін. Раціональна фармакотерапія. 2011. Спеціальній номер. C. 12-14. URL: http://rpht.com.ua/ua-issue-article-1392\#Analiz-spontannih-povidomlen-propobichni-reakciyi-na-likarski-zasobi (дата звернення: 07.05.2020).

18. Матвєєва О. В., Зіменковський А. Б., Яйченя В. П. Побічні реакції на лікарські засоби як одна 3 ліко-пов'язаних помилок та їх зв'язок із медичною помилкою (повідомлення I). Раціональна фармакотерапія. 2012. № 4 (25). C. 5-9. URL: http://rpht.com.ua/ua-issue-article-1438 (дата звернення: 07.05.2020).

19. Несприятливі події після імунізації. О. Сахнюк, О. В. Матвєєва, Г. Мойсеєва та ін. Раціональна фармакотерапія. 2013. № 3 (28). C. 5-13. URL: http://rpht.com.ua/uploads/files/2013/3\%20 (28)/82935084.pdf (дата звернення: 07.05.2020).

20. Державний експертний центр МОЗ України: Основні показники роботи системи фармаконагляду України за 2017 рік. URL: https://dec.gov.ua/materials/osnovni-pokazniki-roboti-sistemifarmakonaglyadu-ukra-ni-za-2017-rik/?role=doctors (дата звернення: 21.05.2020). 
21. Державнийекспертнийцентр МОЗ України:Основніпоказники роботи системи фармаконагляду України за 2018 рік. URL: https://dec.gov.ua/materials/osnovni-pokazniki-roboti-sistemi-farmakonaglyadu-ukra-ni-za-2018-rik/?role=doctors (дата звернення: 21.05.2020).

22. Державнийекспертнийцентр МОЗУкраїни:Основніпоказники роботи системи фармаконагляду України за 2019 рік. URL: https://dec.gov.ua/materials/osnovni-pokaznyky-roboty-systemy farmakonaglyadu-ukrayiny-za-2019-rik/?role=doctors (дата звернення: 21.05.2020).

23. Матвєєва О. В., Яйченя В. П. Відсутність ефективності... Новини медицини та фармації. 2014. № 4 (448). C. 7. URL: http://www.mif-ua.com/archive/article/38152 (дата звернення: 11.06.2020).

24. The value of reporting therapeutic ineffectiveness as an adverse drug reaction. R. Meyboom, M. Lindquist, A. K. Flygare at al. Drug Saf. 2000. № 23(2). P. 95-99.

25. Об'єктивно про фармаконагляд в Україні. Apteka.ua. 2014. № 46 (967). URL: https://www.apteka. ua/article/314135 (дата звернення: 21.05.2020).

26. Ошибки применения лекарственных препаратов: современное состояние проблемы. А. В. Кузьмина, И. Л. Асецкая, С. К. Зырянов, В. А. Поливанов. Лечебное дело. 2015. № 3. С. 17-27. URL: https://cyberleninka.ru/article/n/oshibki-primeneniya-lekarstvennyh-preparatov-sovremennoesostoyanie-problemy (дата звернення: 05.05.2020).

27. Всемирная организация здравоохранения: ВОЗ выступает с глобальной инициативой по сокращению числа ошибок применения лекарственных средств в два раза в течение 5 следующих лет. URL: https://www.who.int/mediacentre/news/releases/2017/medication-relatederrors/ru/ (дата звернення: 07.05.2020).

28. Медицинские ошибки при применении антибактериальных препаратов группы цефалоспоринов. А. В. Кузьмина, И. Л. Асецкая, В. А. Поливанов и др. КМАХ. 2017. № 1. С. 18-24. URL: https://cyberleninka.ru/article/n/meditsinskie-oshibki-pri-primeneniiantibakterialnyh-preparatovgruppy-tsefalosporinov (дата звернення: 06.05.2020).

29. Борецька О. Б., Зіменковський А. Б. Розробка моделі класифікаційної системи ліко-пов'язаних проблем (DRP) для застосування у вітчизняному аптечному закладі. Клінічна фармація, фармакотерапія та медична стандартизація. 2011. № 1-2. С. 131-136.

30. Городнича О. Ю., Зіменковський А. Б., Матвєєва О. В. Адаптація європейської системи оцінки ліко-пов'язаних проблем (DRP) до аналізу спонтанних повідомлень про побічні реакції лікарських засобів в Україні. Клінічна фармація, фармакотерапія та медична стандартизація. 2011. № 1-2. С. 23-31.

31. Зіменковський А. Б., Ривак Т. Б. Апробація оцінки якості фармакотерапії за стандартизованою методикою PCNE v 5.01 з виявлення DRP на прикладі реального клінічного випадку. Клінічна фармація, фармакотерапія та медична стандартизація. 2011. № 3-4. С. 8-13.

32. Зіменковський А. Б., Ривак Т. Б., Ханик Н. Л. Концепція DRP як частина філософії раціональної фармакотерапії, інтегрованої з системою фармацевтичної опіки. Клінічна фармація, фармакотерапія та медична стандартизація. 2011. № 1-2. С. 214-219.

\section{Т. М. Думенко, О. П. Яворовський, Ю. М. Скалецький, Р. П. Брухно, Т. О. Зінченко, М. М. Риган Пріоритетні проблеми системи фармаконагляду в формуванні безпеки пацієнтів і лікарняного середовища}

Мета дослідження - на основі даних аналізу літератури й електронних інформаційних баз визначити пріоритетні проблеми фармаконагляду для створення безпеки пацієнтів і безпечного лікарняного середовища.

Дослідження виконано з використанням бібліосемантичного аналізу (інформаційно-аналітичного узагальнення даних з наукових літературних джерел).

За даними наукової літератури визначено основні завдання та цілі системи фармаконагляду й оцінено її значення в формуванні безпеки лікарняного середовища та, зокрема, безпечності застосування лікарських засобів. Визначено комплекс заходів, спрямованих на зменшення частоти медичних помилок, розвитку побічних реакцій і запобігання випадкам неефективності лікарських засобів й, як наслідок, на підвищення безпеки лікарняного середовища.

Проблема безпеки лікарняного середовища $є$ актуальною для всіх країн і всіх систем охорони здоров'я, а забезпечення безпечного застосування лікарських засобів є однією з найважливіших ії складових. Побічні реакції, помилки та випадки неефективності ліків, які виникають під час використання лікарських засобів, є важливими складовими небезпеки лікарських засобів. Робота систем фармаконагляду відіграє важливу роль в убезпеченні пацієнта шляхом зменшення ризиків виникнення побічних дій і помилок за використання лікарських засобів, попередження неефективності медикаментозної терапії та здатна оптимізувати витрати на систему охорони здоров'я. Розробка нових і вдосконалення існуючих підходів до профілактики несприятливих наслідків медикаментозної терапії є вкрай актуальними та необхідними в умовах сучасної медицини. Ці заходи в світовому масштабі дозволять врятувати мільйони життів і сприятимуть економії матеріальних ресурсів.

Ключові слова: лікарські засоби, побічна дія, неефективність, медичні помилки, система фармаконагляду 
Т. М. Думенко, А. П. Яворовский, Ю. Н. Скалецкий, Р. П. Брухно,

Т. А. Зинченко, М. М. Рыган

\section{Приоритетные проблемы системы фармаконадзора в формировании безопасности пациентов и больничной среды}

Цель исследования - на основе данных анализа литературы и электронных информационных баз определить приоритетные проблемы фармаконадзора для обеспечения безопасности пациентов и больничной среды.

Исследование выполнено с использованием библиосемантического анализа (информационноаналитического обобщения данных из научных литературных источников).

По данным научной литературы определены основные задачи и цели системы фармаконадзора и оценено ее значение в обеспечении безопасности больничной среды и, в частности, безопасности применения лекарственных средств. Определен комплекс мероприятий, направленных на уменьшение частоты медицинских ошибок, развития побочных реакций и предотвращение случаев неэффективности лекарственных средств и, как следствие, на повышение безопасности больничной среды.

Проблема безопасности больничной среды является актуальной для всех стран и всех систем здравоохранения, а обеспечение безопасного применения лекарственных средств является одной из важнейших ее составляющих. Побочные реакции, ошибки и случаи неэффективности лекарств, которые возникают при использовании лекарственных средств, являются важными составляющими их опасности. Работа система фармаконадзора играет важную роль в обеспечении безопасности пациента путем снижения рисков возникновения побочных действий и ошибок при использовании лекарственных средств, предупреждения неэффективности медикаментозной терапии и способна оптимизировать расходы на систему здравоохранения. Разработка новых и совершенствование существующих подходов к профилактике неблагоприятных последствий медикаментозной терапии являются крайне актуальными и необходимыми в условиях современной медицины. Эти меры в мировом масштабе позволят спасти миллионы жизней и будут способствовать экономии материальных ресурсов.

Ключевые слова: лекарственные средства, побочное действие, неэффективность, медицинские ошибки, система фармаконадзора

\section{T. M. Dumenko, A. P. Yavorovsky, Yu. M. Skaletsky, R. P. Brukhno, \\ T. O. Zinchenko, M. M. Regan \\ Priority problems of the pharmacovigilance system in formation of patient and hospital environment safety}

The purpose - to identify priority pharmacovigilance issues to ensure patient safety and a safe hospital environment based on an analysis of scientific literature sources and public databases.

The research performed using bibliosemantic analysis (information and analytical synthesis of data from scientific literature sources).

According to the scientific literature, the main goals and objectives of the pharmacovigilance system are determined and its importance in ensuring the safety of the hospital environment and, in particular, the safety of medicines use is assessed. The role of medical errors, adverse reactions and inefficiency under drugs use in the formation of the dangers of the hospital environment were evaluated. A set of measures aimed at reducing the frequency of medical errors, adverse reactions developing, and preventing the cases of medicines inefficiency and, as a result, improving the safety of the hospital environment has been determined

The problem of the safety of the hospital environment is urgent for all countries and all health systems, and ensuring the safe use of medicines is one of its most important components. Adverse reactions, errors, and cases of drug inefficiency that occur when using drugs are an important components of the drugs danger. The pharmacovigilance system plays an important role in ensuring the safety of the patient by reducing risks of side effects and errors in the use of drugs, preventing the inefficiency of drug therapy, and can optimize the costs of the health system. The development of new and improvement of existing approaches to the prevention of the adverse consequences of drug therapy are extremely relevant and necessary for modern medicine. These measures on a global scale will save millions of lives and material resources.

Key words: drugs, side effects, ineffectiveness, drug errors, pharmacovigilance system

Надійшла: 3 червня 2020 p.

Прийнята до друку: 31 серпня 2020 р.

Контактна особа: Брухно Роман Петрович, асистент, кафедра гігієни та екології, Національний медичний університет імені О. О. Богомольця, буд. 34, просп. Перемоги, м. Київ, 03057. Тел.: + 3806812759 15. Електронна пошта: bruhnoroman@ukr.net 